\title{
Pemberdayaan Masyarakat Terhadap Pemanfaatan Tanaman Obat Keluarga (Toga) di Masa Pandemi Covid-19 di Dusun Topore Selatan Desa Topore Kabupaten Mamuju
}

\author{
Akbar Nur ${ }^{1}$, Aslindah ${ }^{2}$, Sri Wulan Handayani ${ }^{3}$, Nur A'izan ${ }^{4}$, Gapur $^{5}$ \\ ${ }^{1}$ Dosen Program Studi Ilmu Keperawatan, STIKes Andini Persada Mamuju \\ 2,3,4Mahasiswa Program Studi Ilmu Farmasi, STIKes Andini Persada Mamuju \\ ${ }^{5}$ Mahasiswa Program Studi Ilmu Keperawatan, STIKes Andini Persada Mamuju \\ *e-mail: akbarskep@gmail.com ${ }^{1}$
}

\begin{abstract}
Abstrak
COVID-19 merupakan keluarga besar virus yang menyebabkan penyakit ringan sampai berat bahkan dapat mengakibatkan kematian. Beberapa gejala diantaranya seperti common cold atau pilek, flu, radang tenggorokan, demam tinggi, nyeri otot. popularitas tanaman obat semakin meningkat. Masyarakat percaya bahwa menggunakan obat tradisional seperti jamu dari rimpang jahe, kunyit, temulawak atau kencur dapat meningkatkan imunitas tubuh. Masyarakat dapat melakukan penanaman toga di lahan yang kosong, Dusun Topore Selatan merupakan salah satu Desa yang sebagian Masyarakat masih belum mengetahui tentang khasiat tanaman obat keluarga dan cara pengolahan yang baik dan benar. Selain itu, tanaman obat keluarga dapat dibudidayakan secara individual dan memanfaatkannya sehingga akan terwujud prinsip kemandirian dalam pengobatan keluarga. Apalagi di masa pandemi Covid-19 ini, mengolah jamu untuk menjaga kesehatan dengan bahan yang berasal dari hasil tanaman sendiri akan sangat membantu menjaga sistem imun. Berdasarkan analisis permasalahan yang dihadapi oleh masyarakat, maka beberapa usaha dapat dilakukan sebagai solusi untuk memberdayakan masyarakat Dusun Topore Selatan dalam peningkatan pemanfaatan tanaman obat keluarga di masa pandemi covid-19. Kegiatan ini dilakukan dengan metode observasi, penyuluhan, pendampingan dan demonstrasi pembuatan jamu dari tanaman obat keluarga. Upaya pemberdayaan masyarakat yang berbasis keluarga binaan dalam pemanfaatan tanaman obat keluarga dimasa pandemi sangat efektif dilakukan karena dapat meningkatkan pengetahuan dan pemahaman masyarakat dalam pengelolaan dan pemanfaatan tanaman obat keluarga sebagai upaya untuk pemeliharaan kesehatan, pencegahan penyakit dan perawatan kesehatan.
\end{abstract}

Kata kunci: Pemberdayaan, Pemanfaatan TOGA, Covid-19

\begin{abstract}
COVID-19 is a large family of viruses that cause mild to severe illness and even death. Some of the symptoms include common cold or runny nose, flu, sore throat, high fever, muscle aches. The popularity of medicinal plants is increasing. People believe that using traditional medicines such as herbs from the ginger rhizome, turmeric, temulawak or kencur can increase the body's immunity. The community can plant toga on vacant land, Dusun Topore Selatan is one of the villages where some people still do not know about the efficacy of family medicinal plants and proper and correct processing methods. In addition, family medicinal plants can be cultivated individually and utilize so that the principle of independence in family medicine will be realized. Especially during this Covid-19 pandemic, processing herbs to maintain health with ingredients derived from plants themselves will help maintain the immune system. Based on the analysis of the problems faced by the community, several efforts can be made as a solution to empower the people of Dusun Topore Selatan in increasing the use of family medicinal plants during the COVID-19 pandemic. This activity was carried out using the method of observation, counseling, mentoring, and demonstration of making herbal medicine from family medicinal plants. Community empowerment efforts based on fostered families in the use of family medicinal plants during a pandemic are very effective because they can increase community knowledge and understanding in the management and use of family medicinal plants as an effort to maintain health, prevent disease, and health care.
\end{abstract}

Keywords: Empowerment, Utilization of Family Medicinal Plants, Covid-19

\section{PENDAHULUAN}

Corona virus Disease atau yang biasa dikenal dengan sebutan COVID-19 adalah suatu 
jenis penyakit baru yang belum pernah diidentifikasi sebelumnya pada manusia. COVID-19 merupakan keluarga besar virus yang menyebabkan penyakit ringan sampai berat bahkan dapat mengakibatkan kematian. Beberapa gejala diantaranya seperti common cold atau pilek, flu, radang tenggorokan, demam tinggi, nyeri otot dan penyakit yang serius seperti MERS dan SARS. $[1,2]$.

Berdasarkan data Pusat Krisis Kesehatan (PKK) Kemenkes RI sampai tanggal 13 April 2020 Indonesia terkonfirmasi ada 4.557 kasus, meninggal 399, dan sembuh 380 orang. Padahal pada tanggal 3 Maret 2020 ketika ditemukan pertama kali hanya ada 2 kasus terinfeksi coronavirus (COVID-19) dan dua orang tersebut telah dinyatakan sembuh. Jumlah kasus yang dikonfirmasi terus tumbuh secara eksponensial, WHO menandai peristiwa monumental ini dengan mengingatkan semua negara dan komunitas bahwa melakukan kegiatan pencegahan dan pengendalian yang kuat agar dapat secara signifikan memperlambat atau menghentikan penyebaran virus ini $[3,4]$.

Pada masa pandemi covid-19 beberapa tanaman herbal di percaya dalam mencegah covid-19. Pemerintah cina menyatakan secara resmi bahwa obat tradisionalnya dapat meringankan gejala, mempercepat penyembuhan dan mengurangi angka kematian pada kasus covid-19 Hasil penelitian Bioinformatika menunjukkan bahwa senyawa aktif dari herbal dapat berikatan dengan protein virus SARS-CoV-2 sehingga berpotensi sebagai substansi untuk mencegah atau mengobati covid-19. Bentuk upaya promosi dilakukan dalam hal ini, yang tidak terlepas dari upaya pemutusan mata rantai penularan dan menghentikan penularan, yang salah satunya dapat dilankukan dengan upaya peningkatan sistem imun tubuh [5].

Pengobatan tradisional dengan menggunakan tumbuhan telah dilakukan sejak dahulu secara turun temurun oleh masyarakat Indonesia. Meskipun pengobatan modern telah berkembang hingga ke daerah pedesaan, namun penggunaan tumbuhan sebagai obat masih tetap diminati masyarakat dan saat ini semakin berkembang. Sejak merebaknya Covid-19 ini, masyarakat harus lebih memperhatikan makan atau minuman yang akan dikomsumsi agar meningkatkan daya tahan tubuh ditengah masa pandemi covid-19 dikarena virus ini menyerang sistem pertahanan tubuh yang lebih. Kekebalan tubuh yang kuat dipercaya akan menghindarkan diri dari terkena wabah virus tersebut. Masyarakat percaya bahwa menggunakan obat tradisional seperti jamu dari rimpang jahe, kunyit, temulawak atau kencur, dapat meningkatkan imunitas tubuh [6].

World Health Organization (WHO) merekomendasikan penggunaan obat tradisional termasuk obat herbal dalam pemeliharaan kesehatan masyarakat, pencegahan dan pengobatan penyakit, terutama untuk kronis, penyakit degeneratif dan kanker [5]. Tanaman obat keluarga (TOGA) menjadi salah satu pilihan masyarakat untuk ditanam di lahan pekarangan, dengan pertimbangan karena dapat dimanfaatkan untuk kesehatan. Tanaman obat dapat dijadikan obat yang aman, tidak mengandung bahan kimia, murah, dan mudah didapat. Pemanfaatan obat tradisional tersebut sebagai upaya untuk pemeliharaan kesehatan, pencegahan penyakit dan perawatan kesehatan termaksud pada masa kedaruratan kesehatan masyarakat dan atau bencana nasional Corona Virus Disease 2019 (COVID 19) [7].

Pemberdayaan merupakan suatu konsep untuk memberikan tanggung jawab yang lebih besar kepada orang-orang tentang bagaimana melakukan pekerjaan. Pemberdayaan akan berhasil jika dilakukan dengan sungguh-sungguh, kelompok yang dilakukan secara terstruktur dengan membangun budaya kerja yang baik. Konsep pemberdayaan dan pembangunan yang bertumpu pada masyarakat. Pemberdayaan masyarakat dapat diartikan sebagai upaya untuk memulihkan atau meningkatkan kemampuan suatu komunitas untuk mampu berbuat sesuai dengan harkat dan martabat mereka dalam melaksanakan hak-hak dan tanggung jawabnya selaku anggota masyarakat [8].

Namun berdasarkan studi pendahuluan yang dilakukan di Dusun Topore Selatan 
terkait pemanfaatan tanaman obat keluaraga TOGA dimasa pandemic ini, ditemukan bahwa masih terdapat masyarakat belum mengetahui apa yang di maksud dengan tanaman obat keluarga dan bagaimana cara pengelolaanya maka dari itu perlu melakukan edukasi dan demonstrasi tentang tanaman obat keluarga (TOGA).

Berdasarkan uraian latar belakang diatas menunjukkan bahwa pentingnya meningkatkan pengetahuan dan cara pemanfaatan tanaman obat keluarga TOGA ditengah masyarakat, apalagi dimasa pandemi saat ini masyarakat banyak memanfaatkan tanaman herbal untuk meningkatkan stamina atau sistem imun agar dapat terhindar dari covid-19. Oleh karena itu, kegiatan pengabdian masyarakat ini melakukan Pemberdayaan Masyarakat Terhadap Pemanfaatan Tanaman Obat Keluarga TOGA dimasa Pandemi covid-19 yang dilakukan di Dusun Topore Selatan Desa Topore Kecamatan Papalang Kabupaten Mamuju.

Target luaran pada kegiatan ini adalah membuat modul terkait pemanfaatan tanaman obat keluarga TOGA dimasa pandemic covid-19 selain itu diharapkan masyarakat dapat memanfaatakan pekarangan samping rumah untuk ditanami beberapa tanaman herbal serta pemanfaatan budidaya tanaman herbal dan pembuatan minuman herbal

\section{METODE}

Metode tahap persiapan pelaksanaan kegiatan pengabdian masayarakat ini terlebih dahulu dilakukan survey, kemudian mengurus surat permohonan izin/rekomendasi pelaksanaan kegiatan pengabdian masayarakat ini. Pada tahapan pelaksanaan terlebih dahulu melakukan kunjungan ke beberapa rumah warga guna untuk melakukan observasi terkait pengetahuan dan kebiasaan masayarakat dalam menggunakan tanaman herbal yang mudah ditemukan disekitar pemukiman warga Dusun Topore Selatan. Setelah melakukan kunjungan ke bebarapa rumah warga maka langkah selanjutnya menentukan keluarga binaan guna untuk dilakukan Pemberdayaan Masyarakat Terhadap Pemanfaatan Tanaman Obat Keluarga dimasa Pandemi covid-19 program ini di desain untuk membuat salah satu percontohan pada masyarrakat setempat.

Keluarga binaan diberikan edukasi terkait tanaman obat keluarga dan manfaat TOGA serta melakukan demosntrasi cara pengolahan minuman herbal sebagai upaya untuk meningkatkan imunitas tubuh dimasa pandemi covid 19. Tahap selanjutnya menyiapkan pekaranagan kosong yang siap untuk dilakukan penanaman beberapa jenis tanaman TOGA guna untuk dijadikan sebagai TOGA percontohan serta melakukan evaluasi dan tindak lanjut program pemberdayaan masayarakat terhadap penggunaan Tanaman Obat Keluarga (TOGA).

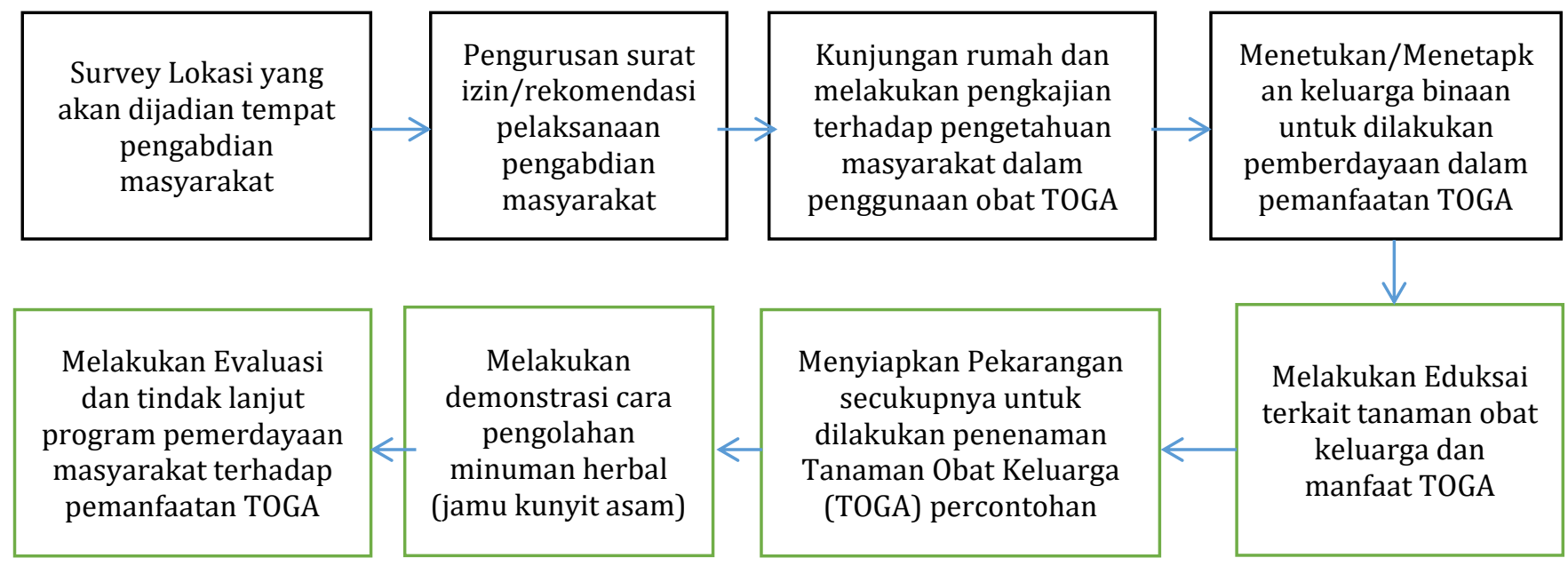

Gambar 1. Flowchart Pelaksanaan Kegiatan Pengabdian Masyarakat 


\section{HASIL DAN PEMBAHASAN}

Keluarga binaan merupakan salah satu keluarga yang dipilih dengan tujuan untuk diberikan edukasi terkait tanaman obat keluarga dan manfaat TOGA serta melakukan demosntrasi cara pengolahan minuman herbal sebagai upaya untuk meningkatkan imunitas tubuh dimasa pandemi covid 19 dan bagaimana cara keluarga dalam menangani masalah penyakit-penyakit ringan dengan menjadikan tanaman Toga sebagai obat nonfarmakologi alternatif.

Pemberian edukasi tentang tanaman toga yang sangat di butuhkan untuk menjaga kesehatan keluarga binaan bertujuan untuk meningkatkan kesadaran, kemauan, dan kemampuan hidup sehat bagi setiap orang agar terwujud derajat kesehatan keluarga yang setinggi-tingginya sebagai inventasi bagi pembangunan sumber daya manusia yang produktif secara sosial dan ekonomis. Pemberdayaan tanaman obat keluarga dalam penanaman dan pemanfaatan Tanaman obat keluarga (TOGA) salah satunya dapat digunakan untuk mendukung pemberdayaan dengan pemanfataan lingkungan yang ada di wilayah tersebut. Tanaman obat keluarga (TOGA) adalah tanaman hasil budidaya rumahan yang berkhasiat sebagai obat [9].

Menurut pertiwi obat covid-19 belum ditemukannya secara spesifik yang dapat digunakan untuk menyembuhkan penderita yang terinfeksi COVID-19. Terapi yang digunakan hanyalah untuk menghilangkan gejala yang muncul dan meningkatkan imunitas penderita agar kuat melawan virus tersebut. Pemerintah juga menghimbau seluruh masyarakat untuk meningkatkan imunitas tubuh agar terhindar dari infeksi COVID-19. Imunitas tubuh dapat ditingkatkan dengan menerapkan prilaku pola hidup sehat. Pola hidup sehat meliputi pola makan dengan asupan nutrisi yang seimbang, dan olahraga. Nutrisi tambahan dapat berupa mengkonsumsi rempah-rempah seperti minuman jahe dan kunyit.

Tanaman obat keluarga banyak digunakan sebagai bahan baku obat tradisional dan jamu, yang apabila dikonsumsi dapat meningkatkan kekebalan tubuh (immune system), karena tanaman ini mempunyai sifat spesifik sebagai tanaman obat yang bersifat pencegahan (preventif) dan promotif melalui kandungan metabolit sekunder contohnya seperti gingiro pada jahe dan santoriso pada temulawak yang mampu meningkatkan sistem kekebalan tubuh. Jamu tidak dapat menyembuhkan yaitu bersifat kuratif, namun lebih ke arah sebagai pencegahan dengan cara meningkatkan kekebalan tubuh, sehingga lebih bermanfaat untuk mencegah COVID-19 [3].

Tanaman obat keluarga (TOGA) adalah suatu tumbuhan yang ditanam oleh keluarga di sekitar lingkungan rumah yang mempunyai khasiat penyembuhan sebagai apotek hidup yang dimanfaatkan oleh keluarga secara sederhana dan budidaya tanaman yang berkhasiat sebagai obat dalam rangka memenuhi kebutuhan keluarga akan obat- obatan [1].

Pemanfaatan TOGA juga dapat digunakan untuk mengatasi masalah-masalah kesehatan secara tradisional (obat). Kenyataan menunjukan bahwa obat yang berasal dari sumber bahan alami khususnya tanaman telah memperlihatkan perannya dalam penyelenggaraan upayaupaya kesehatan masyarakat. Pemanfaatan TOGA yang digunakan untuk pengobatan gangguan kesehatan keluarga menurut gejala umum adalah: panas, batuk, sakit gigi, sakit perut, dan gatalgatal.

Pemanfaatan tanaman obat keluarga (TOGA) yang lebih alami oleh masyarakat Indonesia, secara turun- temurun sebagai warisan budaya bangsa. Tanaman obat tradisional digunakan dan dilaporkan secara empirik oleh masyarakat bermanfaat meningkatkan kesehatan dan pengobatan berbagai penyakit. Penggunaan tana- man obat secara tradisional semakin disukai karena efek samping yang rendah, efek yang saling mendukung dengan obat tradisional lain, lebih sesuai untuk berbagai penyakit metabolik dan degeneratif. Selain itu, obat tradisional dapat diperoleh, diramu dan ditanam sendiri tanpa tenaga medis [9].

Pada kegiatan pengabdian masyarakat ini diharapkan agar kegiatan atau program pemberdayaan ini dapat menjadi program percontohan di Desa Topore Kabupaten Mamuju. Selain itu diharapkan dapat menjadi program yang terus berkesinambungan dan dapat dilanjutkan sehingga masyarakat bisa memanfaatkan tanaman ini sebagai solusi kesehatan keluarga dan tidak selalu tergantung dengan pengobatan medis. 
Pada kegiatan ini telah dilakukan demonstrasi bersama keluarga binaan terkait cara membuat obat tradisional yang terbuat dari bahan utamanya yaitu kunyit kuning dan asam jawa adapun bahan tambahanya yaitu garam dan gula jawa yang berfungsi meningkatkan imun tubuh dan meredakan batuk. Dalam kegiatan ini keluarga binaan ditingkatkan kemampuannya dalam mencari solusi untuk masalah kesehatan secara mandiri sebagai upaya pertolongan pertama dalam keluarga dan memelihara kesehatan melalui pemanfaatan toga, diharapkan dapat menunjang kesehatan kepada keluarga binaan sebagai upaya preventif, promotif, dan kuratif guna untuk peningkatan kesejahteraan serta sebagai sumber penyedia bahan baku tradisional.

Berikut terdapat beberapa foto yang berhasil didokumentasikan pada saat kegiatan berlangsung:

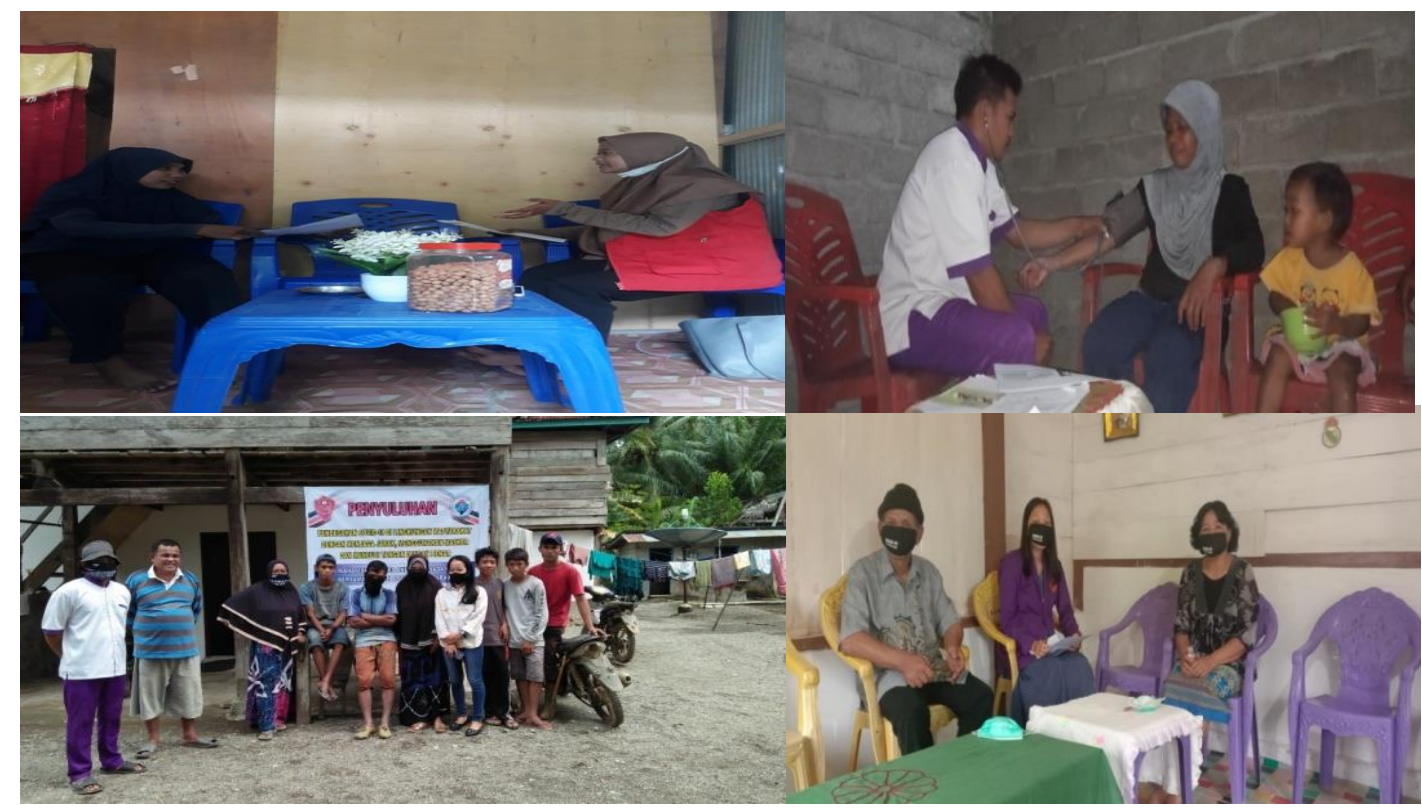

Gambar 2. Melakukan edukasi tentang Tanaman obat Keluarga dikeluarga binaan

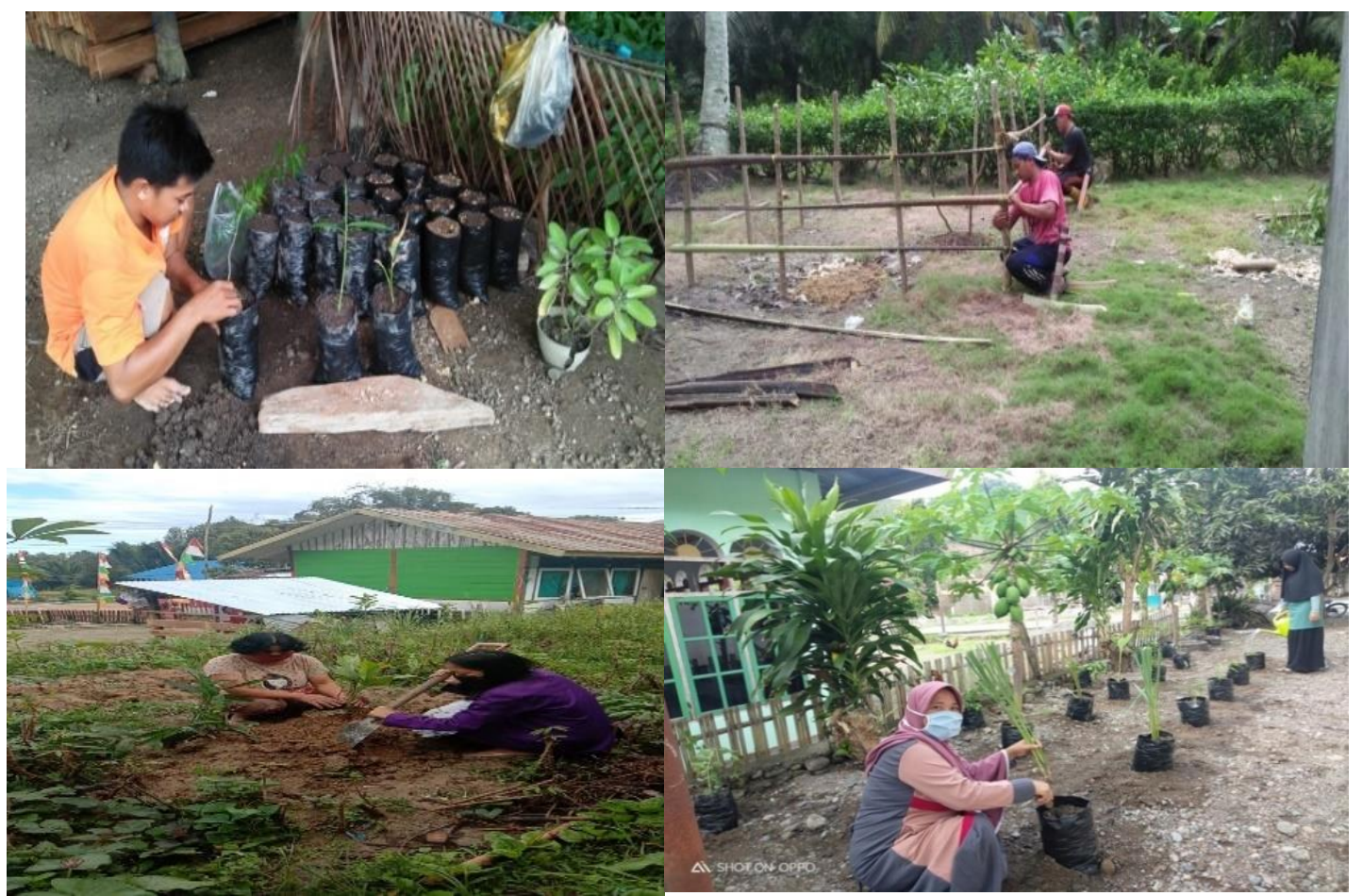

Gambar 3. Proses Pembibitan, Penanaman dan pembuatan pagar untuk penanaman TOGA di keluarga binaan. 
Kegiatan ini dilaksanakan untuk memberikan pengetahuan kepada keluarga binaan mengenai jenis-jenis TOGA dan khasiatnya untuk pengobatan terkhusus dalam masa pandemi COVID-19 sebagai penambah imunitas. Pada kegiatan ini keluarga binaan sangat antusias dalam mengikuti kegiatan edukasi terkait pemanfaatan dan tanaman TOGA dalam meningkatkan sistem imun maupun untuk pengobatan penyakit lainnya.

Pada kegiatan ini dilakukan edukasi kepada masyarakat atau keluarga binaan terkait cara menyiapkan bibit, menyiapkan lahan dan cara penanaman TOGA yang baik kepada keluarga binaan di Dusun Topore Selatan.
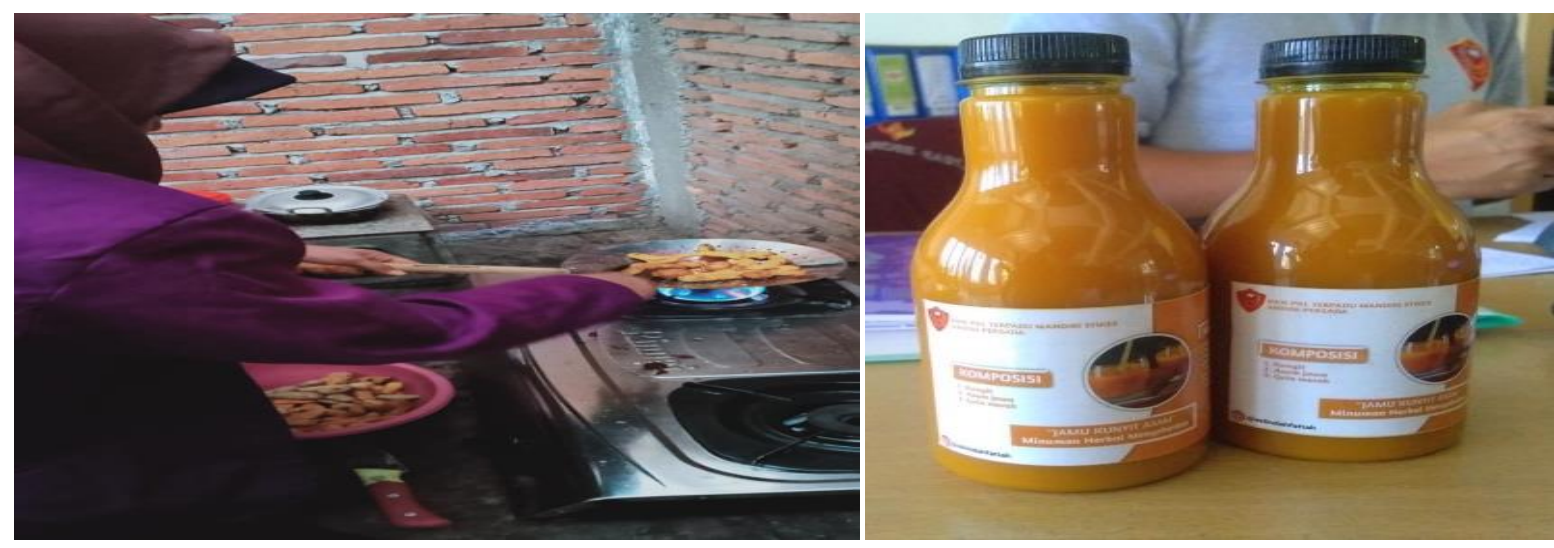

Gambar 4. Proses pembuatan jamu dan dimasukkan ke dalam botol serta diberi label yang memuat terkait bahan dan manfaat dari minuman herbal tersebut.

Pengembangan TOGA saat ini lebih pada aspek budidaya saja dengan pemanfaatan yang belum optimal dan terbatas pada diri serta keluarga saja. Masyarakat yang telah memiliki pengetahuan tentang khasiat TOGA dan menguasai cara pengolahannya dapat membudidayakan tanaman obat secara individual dan memanfaatkannya sehingga akan terwujud prinsip kemandirian dalam pengobatan keluarga [10].

Apalagi di masa pandemi Covid-19 ini, mengolah jamu untuk menjaga kesehatan dengan bahan yang berasal dari hasil tanaman sendiri akan sangat membantu menjaga stabilitas ekonomi. Selain itu juga dapat dikembangkan menjadi usaha kecil dan menengah di bidang obatobatan herbal seperti jamu

Minuman tradisonal khas Indonesia ini memiliki khasiat tinggi. Jamu sering digunakan sebagai bahan metode pengobatan alternatif. Jamu dikenal sejak lama oleh masyarakat kita bahkan sejak abad ke 7 dari kerajaan mataram kuno. Jamu sendiri diracik dari berbagai ramuan herbal yang tentunya memiliki khasiat menyembuhkan berbagai jenis penyakit. TOGA merupakan sumber bahan baku untuk pembuatan jamu. Di era COVID-19 ini jamu menjadi naik permintaan karena khasiatnya yang dipercaya dapat meningkatkan imunitas serta tren masyarakat untuk kembali ke alam. Produk olahan TOGA berpotensi menambah penghasilan jika benar-benar dikelola dengan baik dalam pemanfaatannya dalam bentuk jamu. Ada banyak hal yang harus diperhatikan dalam pengembangannya agar secara ekonomi bisa menambah penghasilan. Rasa, penampilan kemasan, perijinan, serta produk yang hidienis akan sangat penting dalam pengembangan produk jamu dari TOGA.

\section{KESIMPULAN}

Tanaman obat keluarga (TOGA) adalah tanaman hasil budidaya rumahan yang berkhasiat sebagai obat dan bisa mencegah penyakit covid dan menambah imun tubuh. Tujuan menanam Tanaman Obat keluarga (TOGA) antara lain adalah untuk menyiapkan tanaman yang digunakan sebagai obat, untuk pengobatan sendiri maupun untuk keperluan sakit mendadak, misalnya kalau sakit terjadi pada malam hari, sebagai pertolongan pertama sebelum berobat ke dokter. Penggunaan tanaman obat ini tidak perlu mengeluarkan biaya, mengingat tanaman 
tersebut tersedia di pekarangan rumah. Upaya ini sangat dibutuhkan oleh keluarga binaan saat mereka tidak mempunyai biaya.Dari segi keamanannya tanaman obat ini diberikan sebagai obat tanpa penambahan bahan kimia

\section{DAFTAR PUSTAKA}

[1] R. D. Riastuti, I. M. Sustianingsih, "Pelatihan Pemanfaatan Rempah Toga Sebagai Upaya Meningkatkan Sistem Kekebalan Tubuh di Masa Pandemi Covid-19," Bakti Nusantara Linggau J Pengabdi Kpd Masy, vol. 2, no. 1, pp. 41-6, 2021.

[2] M. Probolinggo, "Peran Aktif Masyarakat dalam Menanggulangi Penyebaran Covid-19 di Kecamatan Kademangan Kota Probolinggo," J Gov Policy Innov, vol. 1 pp. 47-56, April, 2021.

[3] R. Pertiwi, D. Notriawan, R. H. Wibowo, "Pemanfaatan Tanaman Obat Keluarga (TOGA) Meningkatkan Imunitas Tubuh sebagai Pencegahan COVID-19," Dharma Raflesia J Ilm Pengemb dan Penerapan IPTEKS, vol. 18, no. 2, pp. 110-8, 2020.

[4] R. Pakaya, F. Ramadhani, S. Hanapi, F. D. Badu, I. Iyou, "Penerapan 3M (Memakai Masker, Mencuci Tangan, dan Menjaga Jarak) dalam Upaya Pencegahan Corona Virus Disease (Covid-19) di Desa Mohiyolo Kec. Asparaga Kabupaten Gorontalo," J Pengabdi Kpd Masy Univ Gorontalo, vol. 3, no. 1, 2021.

[5] A. O. Puteri, F. Fakhriyah, S. Wasilah, N. S. Skripsiana, M. S. Noor, "Pelatihan Pengolahan Produk Jahe Sebagai Upaya Pemberdayaan Masyarakat Di Masa Pandemi Covid-19," J Pengabdi ILUNG (Inovasi Lahan Basah Unggul), vol. 1, no. 1, pp. 59-66, 2021.

[6] K. Anwar, M. Fitriana, "Pemberdayaan Masyarakat Dengan Pemanfaatan Tanaman Obat Keluarga ( Toga ) Dalam Pembuatan Jamu Untuk Meningkatan Imunitas Tubuh Bagi Masyarakat Desa Sungai Besar Kabupaten Banjar Sebagai Pencegahan Covid-19," vol. 3, no. 1, pp. 1-6, 2021.

[7] P. Parawansah, A. Esso, S. Saida, "Sosialisasi Pemanfaatan Tanaman Obat Keluarga Sebagai Upaya Untuk Meningkatkan Imunitas Tubuh Ditengah Pandemi di Kota Kendari," J Community Engagem, vol. 3, no. 2, pp. 325-328, 2020.

[8] W YPA, R. D. F. S. Aulia, R. E. Nadia, H PT, "Pemanfaatan Toga Guna Meningkatkan Kesadaran Masyarakat Terhadap Toga," J Abdi Bhayangkara UBHARA Surabaya, vol. 2, no. 1, pp. 198-202, 2020.

[9] P. Permatasari, R. Hardy, "Dalam Penanaman Dan Pemanfaatan Tanaman Obat Keluarga ( Toga )," J Bakti Masy Indones, vol. 2, no. 1, pp. 129-134, 2019, doi: http://dx.doi.org/10.24912/jbmi.v2i1.4337.

[10] S. P. Nugraha, "Pelatihan Penanaman Tanaman Obat Keluarga (TOGA)," Asian J Innov Entrep, vol. 4, no. 1, pp. 58-62, 2015. 